\title{
Pemilihan Alat Kontrasepsi dalam Rahim (AKDR) pada akseptor Keluarga Berencana
}

\author{
Mita Meilani, ${ }^{1 *}$ Ade Putranto Prasetyo Wijiharto Tunggali ${ }^{2}$ \\ ${ }^{1}$ Magister Kebidanan, Universiyas Aisyiyah Yogyakarta; ${ }^{2}$ Program Studi S1 Komunikasi, \\ Universiyas Aisyiyah Yogyakarta - Indonesia
}

\begin{abstract}
Family Planning is the most basic and primary preventive health service effort. One of the acceptable contraceptives in Indonesia is the Contraceptive Intra Uteri Device (IUD), which is the most effective, safe and comfortable contraception for many women. Use of contraception is still dominated by short-term contraceptives, especially injections which reach $31.2 \%$ and pills $13.4 \%$. While the level of use of the LongTerm Contraception method, the IUD reaches $4.8 \%$. In 2013, based on the results of the KB prevalence survey with MKJP of $64.6 \%$. Overall, there were still 16 provinces that reached the position of family planning prevalence with MKJP lower than the national figure (>64.6\%). This study aims to determine the relationship of maternal characteristics with the selection of contraceptives Intra Uteri Device (IUD) on family planning acceptors at the Kramatwatu Health Center in Serang, Banten. This quantitative study uses a cross sectional approach with 82 acceptor respondents and uses a check list instrument. The results of the research prove that with the results of statistically significant tests showing that there is a relationship between maternal age, maternal parity, maternal education and occupation with the selection of contraceptives intra uteri device on family planning acceptors with $p$-value $0.004<0.05, p$-value $0.007<0$ $.05, p$-value $0.006<0.05$ and $p$-value $0.007<0.05$. The conclusion in this study there is a relationship between maternal characteristics with the IUD selection so that health workers can optimize counseling about family planning, especially the use of intra uterine devices (IUD).
\end{abstract}

Keywords: contraception intra uterine device; parity; education; age

Keluarga Berencana merupakan upaya pelayanan kesehatan preventif yang paling dasar dan utama. Salah satu alat kontrasepsi yang dapat diterima di Indonesia adalah Alat Kontrasepsi Dalam Rahim (AKDR) yang merupakan alat kontrasepsi yang paling efektif, aman dan nyaman bagi banyak wanita. Penggunaan kontrasepsi masih di dominasi oleh alat kontrasepsi jangka pendek terutama suntikan yang mencapai $31,2 \%$ dan pil $13,4 \%$. Sedangkan tingkat pemakaian metode Kontrasepsi Jangka Panjang yaitu AKDR mencapai 4,8\%. Pada tahun 2013, berdasarkan hasil survey prevalensi KB dengan MKJP sebesar $64,6 \%$. Secara keseluruhan masih 16 provinsi mencapai posisi prevalensi KB dengan MKJP lebih rendah dari angka nasional (>64,6\%). Penelitian ini bertujuan untuk mengetahui Hubungan karakteristik ibu dengan pemilihan alat kontrasepsi dalam rahim (AKDR) pada akseptor KB di Puskesmas Kramatwatu Serang Banten. Penelitian kuantitatif ini menggunakan pendekatan cross sectional dengan 82 responden akseptor KB dan menggunakan instrumen check list. Hasil penelitian membuktikan bahwa dengan hasil uji statistik yang signifikan menunjukkan bahwa ada hubungan antara umur ibu, paritas ibu, pendidikan ibu dan pekerjaan dengan pemilihan alat kontrasepsi dalam rahim pada akseptor KB dengan $p$-value 0,004<0,05, p-value 0,007<0,05, p-value 0,006<0,05 dan $p$-value 0,007<0,05.

*Korespondensi Penulis: Mita Meilani (email: meilani.mita@yahoo.com), Jl. Raya Cilegon No.KM.8, Pejaten, Kec. Kramatwatu, Serang, Banten 42616 
Kesimpulan dalam penelitian ini ada hubungan karakteristik ibu dengan pemilihan AKDR sehingga tenaga kesehatan dapat mengoptimalkan penyuluhan mengenai keluarga berencana khususnya penggunaan Alat Kontrasepsi Dalam Rahim (AKDR).

Kata Kunci: Alat Kontrasepsi dalam Rahim; paritas; pendidikan; umur

\section{Pendahuluan}

Gerakan KB Nasional adalah gerakan masyarakat yang menghimpun dan mengajak segenap potensi masyarakat untuk berpartisipasi aktif dalam melembagakan dan membudayakan Norma Keluarga Kecil Bahagia Sejahtera (NKKBS) dalam rangka meningkatkan mutu sumber daya manusia. Tujuan umum dari program KB adalah membentuk keluarga kecil sesuai dengan kekuatan sosial ekonomi suatu keluarga, dengan cara pengaturan kelahiran anak agar diperoleh suatu keluarga bahagia dan sejahtera yang dapat memenuhi kebutuhan hidupnya. Sasaran dalam program ini adalah Pasangan Usia Subur (PUS) yang menjadi akseptor KB aktif (Sulistyawati, 2012).

Tahap selanjutnya program KB menjadi gerakan KB yang ditujukan terutama untuk meningkatkan kualitas sumber daya manusia yang dilandasi oleh Undang-undang No. 10 tahun 1992 tentang Kependudukan dan Perkembangan Keluarga Sejahtera. Keluarga Berencana (Family Planning, Planned Parenthood) adalah suatu usaha untuk menjarangkan atau merencanakan jumlah dan jarak kehamilan dengan memakai kontrasepsi. Keluarga berencana dapat meningkatkan kepedulian masyarakat dalam mewujudkan keluarga kecil yang bahagia sejahtera (Anggraini, 2012). Pertumbuhan yang tinggi akan menimbulkan masalah besar bagi suatu negara, sehingga usaha harus optimal dalam mem pertahankan kesejahteraan rakyat (Pinontoan, Solang, \& Tombokan, 2014).
Penggunaan alat kontrasepsi di Indonesia masih didominasi alat kontrasepsi jangka pendek terutama kontrasepsi suntik. Kontrasepsi jangka pendek dapat mengakibatkan angka putus pakai KB cukup tinggi. Alat Kontrasepsi Dalam Rahim (AKDR) yang merupakan alat kontrasepsi yang paling efektif, aman dan nyaman bagi banyak wanita, alat ini merupakan alat kontrasepsi reversible yang paling sering digunakan di seluruh dunia dengan pemakaian saat ini mencapai sekitar 100 juta wanita (Glasier \& Alisa, 2005). Dalam penelitian Friedman, (2015) mengatakan bahwa remaja yang sudah memiliki anak bisa menggunakan kontrasepsi ini untuk menghindari kehamilan. Sehingga alat kontrasepsi dalam rahim ini efektif untuk menghindari kehamilan. Alat Kontrasepsi Dalam Rahim (AKDR) merupakan alat kontrasepsi yang memiliki efektifitas lebih unggul dibandingkan alat kontrasepsi jangka pendek, tingkat kegagagalannya pun sangat rendah dibandingkan dengan kontrasepsi lainnya (Tang, Maurer, \& Bartz, 2013).

Pencapaian peserta KB baru di Provinsi Banten tahun 2018 sebesar 463.200 (148,65\%) akseptor terhadap Perkiraan Pemerintah Masyarakat (PPM) sebanyak 311.607 peserta KB baru.Cakupan akseptor baru untuk AKDR 27.514 (5,97\%), MOW 2.561 (0,55\%), MOP 1.154 (0,25\%), Kondom 42.466 (9,17\%), Implant 36.513 (7,88\%), Suntik 221.386 (47,79\%), dan Pil 131.606 (28,41\%). Badan Keluarga Berencana dan 
Pemberdayaan Perempuan (BKBPP) Kabupaten Serang, Berdasarkan Perkiraan Pemerintah Masyarakat (PPM), pencapaian peserta KB aktif dari Pasangan Usia Subur (PUS) di Serang sebanyak 275.495 jiwa yang sudah menjadi peserta KB aktif ada 85.890 jiwa. Adapun rincian pemakaian alat kontrasepsinya, AKDR 7.974 orang, Media Operasi Wanita (MOW) 656 orang, Metode Operasi Pria (MOP) 565 orang, Kondom 2346 orang, Implant 5.522 orang, Suntik 38.948 orang, dan Pil 29.879 orang.

Berdasarkan data yang diperoleh pada periode 01 Januari - 31 Desember 2018 di Puskesmas Kramatwatu, yang menjadi pasangan usia subur 15.763, dan peserta KB aktif adalah 10102 orang yang terdiri dari peserta KB AKDR: 1.037 orang (6,58\%), KB MOW: 363 orang (2,3\%), KB MOP: 57 orang (0,36\%), KB Implant: 555 orang (3,52\%), KB Suntik: 6151 orang $(39,02 \%)$, KB Pil: 1739 orang (11,03\%), dan KB Kondom: 200 orang (1,27\%) (Puskesmas Kramatwatu, 2013). Sedangkan cakupan Peserta KB aktif tahun 2018 dari jumlah peserta KB aktif sebanyak 10102 orang yaitu AKDR (7,19\%), MOW (2,51\%), MOP $(0,93 \%)$, Implant $(3,85 \%)$, Suntik $(42,62 \%)$, Pil $(12,05 \%)$, Kondom (1,38\%). Melihat data tersebut AKDR masih rendah cakupannya karena belum mencapai target tahun 2018.

\section{Metode Penelitian}

Desain penelitian yang digunakan pada penelitian ini adalah survey analitik dengan pendekatan cross sectional. Populasi dari penelitian ini adalah seluruh ibu yang menggunakan kontrasepsi di Puskesmas Kramatwatu sebanyak 450 akseptor KB. Jumlah sampel dalam penelitian ini 82 akseptor KB. Teknik pengambilan sampel menggunakan random sampling secara acak sistematis. Kriteria inklusi penelitian ini adalah ibu yang menjadi akseptor KB, data kontrasepsi yang terekam di buku register bidan, ibu yang memiliki suami, dan kriteria ekslusi yaitu data kontrasepsi yang tidak lengkap di buku register serta menolak menjadi responden.

Instrumen penelitian ini berupa check list yang dibuat oleh peneliti yang berkaitan dengan pencatatan data. Alat pengumpulan data yang digunakan dalam penelitian ini adalah data sekunder dengan melihat buku register KB di Puskesmas. Variabel bebas (variable independent) adalah umur, paritas, pendidikan, dan pekerjaan. Variabel terikat (variable dependent) adalah pemilihan alat kontrasepsi dalam rahim. Analisis nivariat dilakukan dengan statistik deskriptif untuk mendeskripsikan karakteristik setiap variabel penelitian. Analisis bivariat menggunakan uji Chi-Square.

\section{Hasil dan Pembahasan}

Karakteristik responden sebagian besar yang tidak memilih alat kontrasepsi dalam rahim yaitu sebanyak 44 responden (53,7\%). Sebagian besar karakteristik responden berusia 20-35 tahun yaitu sebanyak 50 responden (61\%). Sebagian besar responden dengan paritas 1-3 anak yaitu sebanyak 44 responden (53,7\%). Karakteristik pendidikan responden didapatkan hasil bahwa sebagian besar responden berpendidikan tinggi (SMA, MA, SMK) yaitu sebanyak 46 responden (56,1\%). Dan karakteristik responden sebagian besar tidak bekerja sebanyak 44 responden $(53,7 \%)$. 
Tabel 1.

Hubungan Antara Umur dengan Pemilihan Alat Kontrasepsi dalam Rahim (AKDR) di Puskesmas Kramatwatu Tahun 2018

\begin{tabular}{|c|c|c|c|c|c|c|c|c|}
\hline \multirow{4}{*}{ Umur } & \multicolumn{4}{|c|}{ Ibu Yang Memilih Kontrasepsi } & \multirow{3}{*}{\multicolumn{2}{|c|}{ Total }} & \multirow{4}{*}{ P-value } & \multirow{4}{*}{ OR } \\
\hline & & & & & & & & \\
\hline & \multicolumn{2}{|c|}{ Ya } & \multicolumn{2}{|c|}{ Tidak } & & & & \\
\hline & $\mathrm{F}$ & $\%$ & $\mathrm{~F}$ & $\%$ & $f$ & $\%$ & & \\
\hline$<20$ dan $>35$ th & 8 & 9,8 & 24 & 29,3 & 32 & 100 & & \\
\hline $20-35$ th & 30 & 36,5 & 20 & 24,4 & 50 & 100 & 0,004 & 0,222 \\
\hline Total & 38 & 46,3 & 44 & 53,7 & 82 & 100 & & \\
\hline
\end{tabular}

Tabel 2.

Hubungan antara Paritas dengan Pemilihan Alat Kontrasepsi Dalam Rahim (AKDR) di Puskesmas Kramatwatu Tahun 2018

\begin{tabular}{|c|c|c|c|c|c|c|c|c|}
\hline \multirow{3}{*}{ Paritas } & \multicolumn{4}{|c|}{$\begin{array}{c}\text { Ibu Yang Memilih Kontrasepsi } \\
\text { AKDR }\end{array}$} & \multirow{2}{*}{\multicolumn{2}{|c|}{ Total }} & \multirow{3}{*}{$P$-value } & \multirow{3}{*}{ OR } \\
\hline & \multicolumn{2}{|c|}{$\mathrm{Ya}$} & \multicolumn{2}{|c|}{ Tidak } & & & & \\
\hline & $\mathrm{F}$ & $\%$ & $\mathrm{~F}$ & $\%$ & $f$ & $\%$ & & \\
\hline 1-3 anak & 27 & 32,9 & 17 & 20,7 & 44 & 100 & & \\
\hline$>3$ anak & 11 & 13,4 & 27 & 33 & 38 & 100 & 0,007 & 3,898 \\
\hline Total & 38 & 46,3 & 44 & 53,7 & 82 & 100 & & \\
\hline
\end{tabular}

Berdasarkan tabel 1 tersebut menunjukkan bahwa bahwa ibu yang memilih kontrasepsi AKDR proporsi lebih banyak pada ibu yang berumur 20-35 tahun sebanyak 36,5 \% dibandingkan ibu yang berusia <20 dan $>35$ tahun sebanyak $9,8 \%$.

Hasil uji statistic (Chi Square) didapatkan nilai $P=0,004$ yang berarti $P \leq \alpha(0,05)$ sehingga dapat disimpulkan Ho ditolak. Hal ini membuktikan bahwa ada hubungan antara umur dengan pemilihan AKDR. Dengan nilai OR 0,222 berarti ibu umur $<20$ dan $>35$ tahun satu kali berpeluang tidak memilih AKDR dibandingkan ibu yang berumur 20-35 tahun.

Dari tabel diatas menunjukkan bahwa ibu yang memilih kontrasepsi AKDR proporsi lebih besar pada ibu yang memiliki 1-3 anak sebanyak
$32,9 \%$ di bandingkan ibu yang memiliki $>3$ anak sebanyak $13,4 \%$.

Hasil uji statistic (Chi Square) didapatkan nilai $P=0,007$ yang berarti $P \leq \alpha(0,05)$ sehingga dapat disimpulkan Ho ditolak. Hal ini membuktikan bahwa ada hubungan antara paritas dengan pemilihan AKDR. Dengan nilai OR 3,898 berarti ibu memiliki > 3 anak empat kali berpeluang tidak memilih AKDR dibandingkan ibu yang memiliki 13 anak.

Dari Tabel 3 menunjukkan bahwa ibu yang tidak menggunakan alat kontrasepsi AKDR proporsinya lebih besar pada ibu yang berpendidikan Rendah sebanyak 31,7 \% di bandingkan dengan pendidikan tinggi sebanyak $12,2 \%$. 
Tabel 3.

Hubungan antara Pendidikan dengan Pemilihan Alat Kontrasepsi dalam Rahim (AKDR) di Puskesmas Kramatwatu Tahun 2018

\begin{tabular}{|c|c|c|c|c|c|c|c|c|}
\hline \multirow{4}{*}{ Pendidikan } & \multirow{2}{*}{\multicolumn{4}{|c|}{$\begin{array}{c}\text { Ibu Yang Memilih Kontrasepsi } \\
\text { AKDR }\end{array}$}} & \multirow{3}{*}{\multicolumn{2}{|c|}{ Total }} & \multirow{4}{*}{ P-value } & \multirow{4}{*}{ OR } \\
\hline & & & & & & & & \\
\hline & \multicolumn{2}{|c|}{$\mathrm{Ya}$} & \multicolumn{2}{|c|}{ Tidak } & & & & \\
\hline & $\mathrm{F}$ & $\%$ & $\mathrm{~F}$ & $\%$ & $f$ & $\%$ & & \\
\hline Rendah & 10 & 12,2 & 26 & 31,7 & 44 & 100 & & \\
\hline Tinggi & 28 & 34,1 & 18 & 22 & 38 & 100 & 0,006 & 0,247 \\
\hline Total & 38 & 46,3 & 44 & 53,7 & 82 & 100 & & \\
\hline
\end{tabular}

Tabel 4.

Hubungan antara Pekerjaan dengan Pemilihan Alat Kontrasepsi Dalam Rahim (AKDR) di Puskesmas Kramatwatu Tahun 2018

\begin{tabular}{|c|c|c|c|c|c|c|c|c|}
\hline \multirow{4}{*}{ Pekerjaan } & \multicolumn{6}{|c|}{ Ibu Yang Memilih Kontrasepsi } & \multirow{4}{*}{ P-value } & \multirow{4}{*}{ OR } \\
\hline & \multirow{2}{*}{\multicolumn{2}{|c|}{$\mathrm{Ya}$}} & & & \multirow{2}{*}{\multicolumn{2}{|c|}{ Total }} & & \\
\hline & & & \multicolumn{2}{|c|}{ Tidak } & & & & \\
\hline & $\mathrm{F}$ & $\%$ & $\mathrm{~F}$ & $\%$ & $f$ & $\%$ & & \\
\hline Bekerja & 27 & 32,9 & 17 & 20,7 & 44 & 100 & & \\
\hline Tidak Bekerja & 11 & 13,4 & 27 & 32,9 & 38 & 100 & 0,007 & 3,898 \\
\hline Total & 38 & 46,3 & 44 & 53,7 & 82 & 100 & & \\
\hline
\end{tabular}

Hasil uji statistic (Chi Square) di dapatkan $\mathrm{P}=$ 0,006 berarti $P<\alpha(0,05)$ sehingga dapat disimpulkan Ho ditolak. Hal ini membuktikan bahwa ada hubungan antara pendidikan dengan pemilihan alat kontrasepsi AKDR. Dengan nilai OR 0,247 berarti ibu yang berpendidikan rendah satu kali berpeluang tidak memilih AKDR dibandingkan ibu yang berpendidikan tinggi.

Dari Tabel 4 menunjukkan bahwa ibu yang menggunakan alat kontrasepsi AKDR sama proporsinya pada ibu yang bekerja dan tidak bekerja yaitu sebanyak 32,9 \% . Hasil uji statistic (Chi Square) di dapatkan $\mathrm{P}=0,007$ berarti $\mathrm{P}<\alpha(0,05)$ sehingga dapat disimpulkan Ho ditolak. Hal ini membuktikan bahwa ada hubungan antara pekerjaan dengan pemilihan alat kontrasepsi AKDR. Dengan nilai OR 3,898 berarti ibu yang tidak bekerja empat kali berpeluang tidak memilih AKDR dibandingkan ibu yang bekerja.

Hasil analisis data menunjukkan bahwa responden dengan umur 20-35 tahun lebih banyak memilih alat kontrasepsi dalam rahim sebanyak 36,5 \%. Hasil uji Chi-Square yaitu p-value menunjukkan hasil 0,004, sehingga dapat disimpulkan bahwa $p$-values 0,004 < 0,05 dan terdapat hubungan umur dengan pemilihan AKDR di Puskesmas Kramatwatu Serang tahun 2013. Dengan nilai OR 0,222 berarti ibu umur $<20$ dan >35 tahun satu kali berpeluang tidak memilih AKDR dibandingkan ibu yang berumur 20-35 tahun.

Umur adalah masa perjalanan hidup seseorang, mulai dari lahir sampai batas pengumpulan data, tingkat kematangan dan kekuatan 
seseorang akan lebih dewasa dipercaya dari orang yang belum tinggi kedewasaannya. Hal ini adalah bagian dari pengalaman dan kematangan jiwa. (Nursalam, 2003). Hal ini sesuai dengan pernyataan Hartanto (2004) mengatakan bahwa Pasangan usia subur adalah antara 20-30 tahun merupakan periode usia yang paling baik melahirkan dan jumlah anak 2 orang dan jarak antara kelahiran antara 3-4 tahun, sedangkan usia 30 tahun terutama diatas 35 tahun sebaiknya mengakhiri kesuburan setelah mempunyai 2 orang anak, alat kontrasepsi yang sesuai untuk usia 20-35 tahun salah satunya adalah alat kontrasepsi dalam rahim dengan metode perlindungan jangka panjang.

Dari hasil penelitian didapatkan ibu yang berusia 19 tahun yang memilih alat kontrasepsi dalam rahim berjumlah 3 orang, yang berusia 38 tahun berjumlah 5 orang, sedangkan yang berusia 30 tahun berjumlah 15 orang, yang berusia 25 tahun 8 orang dan yang berusia 34 tahun 7 orang. Pada penelitian ini sebagian besar ibu yang berusia antara 20-35 tahun memilih alat kontrasepsi AKDR. Hal ini mungkin dapat dipengaruhi oleh beberapa faktor-faktor lain seperti ibu yang berusia > 30 tahun sebaiknya mengakhiri kesuburan setelah mempunyai 2 orang anak dan kontrasepsi yang sesuai untuk usia 20-35 tahun salah satunya adalah kontrasepsi AKDR dengan metode perlindungan jangka panjang. Penggunaan alat kontrasepsi meningkat pada umur 30-34 hal ini disebabkan karena wanita tidak menginginkan lebih banyak anak sehingga kontrasepsi ini digunakan sebagai upaya dalam mencegah kehamilan yang tidak diinginkan (Mosher, Moreau, \& Lantos, 2016).
Hasil analisis data menunjukkan bahwa responden memilih kontrasepsi AKDR proporsi lebih besar pada ibu yang memiliki 1-3 anak sebanyak 32,9 \%. Hasil uji Chi-Square yaitu $p$ value menunjukan hasil 0,007 , sehingga dapat disimpulkan bahwa $p$-values 0,007 $<0,05$ dan terdapat hubungan paritas dengan pemilihan AKDR di Puskesmas Kramatwatu Serang tahun 2013. Dengan nilai OR 3,898 berarti berarti ibu memiliki > 3 anak empat kali berpeluang tidak memilih AKDR dibandingkan ibu yang memiliki 13 anak.

Paritas adalah banyaknya kelahiran hidup yang dipunyai oleh seorang wanita. (BKKBN, 2006). Menurut (Mochtar, 2012), primipara adalah seorang wanita yang pernah melahirkan bayi hidup pertama kali sedangkan multipara adalah wanita yang pernah melahirkan bayi beberapa kali sampai 5 kali dan grande multipara adalah wanita yang pernah melahirkan bayi 6 kali atau lebih hidup atau mati.

Pada hasil penelitian ini ditemukan ibu yang memiliki kategori paritas 1-3 anak lebih banyak yang menggunakan alat kontrasepsi AKDR dikarenakan ingin meningkatkan kesejahteraan dalam keluarga salah satunya dengan menggunakan alat kontrasepsi yang memiliki efektifitas tinggi yaitu AKDR dengan perlindungan jangka panjang. Hal ini sesuai dengan pernyataan Hartanto (2004) pada ibu multípara yang berusia dibawah 20 tahun dianjurkan menunda kehamilan dengan menggunakan alat kontrasepsi jenis Pil, AKDR, suntik, susuk dan kondom. Pada usia 20-30 tahun dianjurkan untuk menjarangkan kehamilan, cara kontrasepsi yang dianjurkan adalah AKDR, susuk, suntik, pil, kondom. Sesudah 
usia 30 tahun atau pada fase mengakhiri kesuburan dianjurkan menggunakan kontrasepsi mantap, AKDR, susuk, suntik, pil KB, dan kondom.

Hasil analisis data menunjukkan bahwa ibu yang tidak menggunakan alat kontrasepsi AKDR proporsinya lebih besar pada ibu yang berpendidikan rendah sebanyak 31,7\%. Hasil uji ChiSquare yaitu $p$-value menunjukan hasil 0,006, sehingga dapat disimpulkan bahwa $p$-values 0,006 0,05 dan terdapat hubungan pendidikan dengan pemilihan AKDR di Puskesmas Kramatwatu Serang tahun 2013. Dengan nilai OR 0,247 berarti ibu yang berpendidikan rendah satu kali berpeluang tidak memilih AKDR dibandingkan ibu yang berpendidikan tinggi.

Pendidikan adalah usaha untuk membantu individu, kelompok atau masyarakat dalam meningkatkan atau mengembangkan pengetahuan secara optimal. Pendidikan mempengaruhi proses belajar, makin tinggi pendidikan seseorang makin mudah orang tersebut untuk menerima informasi. Dengan pendidikan tinggi maka seseorang akan cenderung untuk mendapatkan informasi, baik dari orang lain maupun dari media massa (Notoatmodjo, 2010). Pendidikan diperkirakan ada kaitannnya dengan pengetahuan ibu tentang KB IUD, hal ini dihubungkan dengan tingkat pengetahuan ibu bahwa seseorang yang berpendidikan lebih tinggi akan mempunyai pengetahuan yang lebih luas dibandingkan dengan tingkat pendidikan rendah (Notoatmodjo, 2010).

Semakin tinggi tingkat pendidikan seseorang semakin mudah orang tersebut mendapatkan informasi. Pendidikan seorang ibu yang rendah memungkinkan ia lambat dalam mengadopsi pengetahuan baru, khususnya tentang hal-hal yang berhubungan dengan pemilihan alat kontrasepsi AKDR. Hal ini sesuai dengan pernyataan Notoatmodjo (2007) pendidikan merupakan fase kunci dalam pembangunan dan merupakan komponen utama kesejahteraan yang berpengaruh terhadap penurunan jumlah fertilitas, morbiditas, pemberdayaan wanita, kualitas penduduk, proses demokrasi, pendewasaan usia perkawinan, penekanan jumlah penduduk, peningkatan gizi dan peningkatan hidup anak. Tingkat pendidikan ibu merupakan salah satu aspek sosial yang umumnya berpengaruh pada tingkat pendapatan keluarga sebagai faktor ekonomi.

Hasil analisis data menunjukkan bahwa ibu yang menggunakan alat kontrasepsi AKDR sama proporsinya pada ibu yang bekerja dan tidak bekerja yaitu sebanyak 32,9\%. Hasil uji statistic (Chi Square) di dapatkan $\mathrm{P}=0,007$ berarti $\mathrm{P}<\alpha$ $(0,05)$ sehingga dapat disimpulkan Ho ditolak. Hal ini membuktikan bahwa ada hubungan antara pekerjaan dengan pemilihan alat kontrasepsi AKDR. Dengan nilai OR 3,898 berarti ibu yang tidak bekerja empat kali berpeluang tidak memilih AKDR dibandingkan ibu yang bekerja.

Menurut penelitian Yalew, Zeleke dan Teferra (2015) mengatakan bahwa status pekerjaan merupakan faktor yang signifikan dengan pemilihan alat kontrasepsi jangka panjang. Status pekerjaan dapat menjadi prediktor yang penting dalam pemilihan alat kontrasepsi dalam rahim. Status ibu yang berkerja 4 kali lebih besar dalam pemilihan alat kontrasepsi dibandingkan dengan ibu yang tidak bekerja. Hal ini sesuai dengan teori 
(Saifuddin, 2010) bahwa penggunaan alat kontrasepsi AKDR akan sangat menguntungkan karena sangat efektif dan praktis, dihubungkan dengan ibu yang bekerja bahwa dengan memakai alat kontrasepsi AKDR ibu akan aman dari kemungkinan hamil untuk jangka waktu yang relatif lama.

\section{Kesimpulan}

Berdasarkan hasil penelitian hubungan umur, paritas, pendidikan dan pekerjaan dengan pemilihan alat kontrasepsi dalam rahim di Puskesmas Kramatwatu Serang Banten dengan hasil uji statistik yang signifikan ( $\mathrm{Ha}$ diterima, Ho ditolak), $p$-value $0,004<0,05$, $p$-value $0,007<0,05$, $p$-value 0,006<0,05 dan $p$-value 0,007 $<0,05$. Sehingga dengan adanya hasil penelitian ini diharapkan tenaga kesehatan dapat mengoptimalkan informasi atau penyuluhan-penyuluhan mengenai pentingnya ber-KB khususnya alat kontrasepsi dalam rahim untuk mensejahterakan keluarga.[]

\section{Daftar Pustaka}

Anggraini, Y. M. (2012). Pelayanan Keluarga Berencana. Yogyakarta: Rohima Press.

Friedman, J. O. (2015). Factors associated with contraceptive satisfaction in adolescent women using the IUD. Journal of Pediatric and Adolescent Gynecology, 28(1), 38-42. https://doi.org/10.1016/j.jpag.2014.02.015

Glasier, A., \& Alisa, G. (2005). Keluarga Berencana dan kesehatan reproduksi. Jakarta: EGC.
Hartanto, H. (2004). Keluarga Berencana dan Kontrasepsi. Jakarta: Pustaka Sinar Harapan.

Mosher, W. D., Moreau, C., \& Lantos, H. (2016). Trends and determinants of IUD use in the USA, 2002-2012. Human Reproduction, 31(8), 1696-1702. https://doi.org/10.1093/ humrep/dew117

Notoatmodjo, S. (2007). Pendidikan dan perilaku kesehatan. Jakarta: Rineka Cipta.

Notoatmodjo, S. (2010). Metodologi penelitian kesehatan. Jakarta: Rineka Cipta.

Pinontoan, S., Solang, S. D., \& Tombokan, S. G. (2014). Faktor-faktor yang berhubungan dengan penggunaan alat kontrasepsi dalam rahim di Puskesmas Tatelu Kabupaten Minahasa Utara. JIDAN (Jurnal IImiah Bidan), 2(2), 17-23.

Sulistyawati, A. (2012). Pelayanan Keluarga Berencana. Jakarta: Salemba Medika.

Tang, J., Maurer, R., \& Bartz, D. (2013). Intrauterine device knowledge and practices: A national survey of obstetrics and gynecology residents. Southern Medical Journal, 106(9), 500-505. https://doi.org/10.1097/SMJ.0b013e3182a5 efOa

Yalew, S., Zeleke, B., \& Teferra, A. (2015). Demand for long acting contraceptive methods and associated factors among family planning senvice users, Northwest Ethiopia: A health facility based cross sectional study. BMC Research Notes, 8(1), 29. https://doi.org/ 10.1186/s13104-015-0974-6 